\title{
Health and Human Rights: New challenges for social responsiveness
}

\author{
Lestie London, Marion Heap and Laurel Baldwin-Ragaven
}

outh Africa's struggle against apartheid discrimination, including
struggles in the health sector, laid the basis for a vibrant engagement of staff and students in human rights research, teaching and outreach in the Health Sciences Faculty at the University of Cape Town (UCT). This article outlines how this early engagement has continued to address new challenges emerging in the postapartheid democratic period in South Africa. Collaboration with nongovernmental organizations in the early 1990s led to the development of the Health and Human Rights Project, which has been at the heart of the Faculty's engagement work on health and human rights ever since. This article explores how its programme of 'Train the Trainers' in health and human rights has resulted in the national adoption of human rights competencies as an essential component of health professionals' skills base. Research has also extended lessons learnt from the apartheid period into work with vulnerable groups, such as rural farm workers and the deaf. Partnerships with civil society 
organisations have been a strong thread of the faculty's engagement work, creating new knowledge and new ways of joint work, including advocacy engagement in civil society movements and the establishment of regional networks. As well, this article discusses how a focus on health professionals' practice, in terms of dealing with potential dual loyalty conflicts and their role as gatekeepers in the health services on matters of patients' rights, has shaped the research agenda. This article illustrates how knowledge production for the public good extends beyond notions of enhancing economic productivity for national development and provides a base for transdisciplinary and transinstitutional engagement. Finally, it is shown how the portfolio of social responsiveness activities in the health and human rights envelope has offered significant and novel mutual benefits to the university and the community.

\section{BACKGROUND}

South Africa experienced an extraordinary range of human rights violations under apartheid that impacted on all sectors of society. The effect of racial discrimination on health was so extreme that it was said: 'if an outsider wished to know what "apartheid" was, an examination of health and health care would have given them excellent insight into this system of segregation, inequality and oppression' (Department of Health 1997). The Truth and Reconciliation Commission's (TRC) investigation of health sector complicity in apartheid era abuses highlighted the myriad ways in which health professionals and their organisations failed to protect the human rights of vulnerable persons and communities under apartheid (TRC 1998). In particular, the TRC singled out the role of universities and higher education institutions for not prioritising meaningful teaching of human rights and ethics in health_professional training, noting that this neglect was instrumental to the wider complicity of the health sector in apartheid abuses (Baldwin-Ragaven et al. 2000). In their recommendations, the TRC argued:

Training in human rights [must] be a fundamental and integral aspect of all curricula for health professionals. This training should address factors affecting human rights practice, such as knowledge, skills, attitudes, and ethical research practices. Knowledge of and competence and proficiency in the standards 
(both national and international) to which [health professionals] will be held accountable should be a requirement for qualification and registration. (TRC 1998)

One of the most egregious cases in which South African doctors collaborated in gross human rights violations was that of Mr Steve Biko, a former medical student and political activist detained by security forces in 1977, whose torture during interrogation by police led to his death, despite being attended by a number of medical doctors (Rayner 1987; Baldwin-Ragaven et al. 1999). In fact, evidence at the inquest into Biko's death indicated the doctors, who included at least one University of Cape Town (UCT) graduate, allowed their clinical judgment in managing Steve Biko's condition to be influenced by police interests:

SK: 'In terms of the Hippocratic Oath, are not the interests of your patients paramount?'

IL: 'Yes'

SK: 'But in this instance they were subordinated to the interests of the security police?'

IL: 'Yes' (Baldwin-Ragaven et al. 1999, pp. 91, 93, emphasis added)

The outcry in response to Biko's death led to the closure of ranks amongst the leadership in the medical profession (Van Heerden 1996), with both the Medical Association of South Africa and the South African Medical and Dental Council attempting to cover up his torture and the complicity of the doctors' involved (BaldwinRagaven et al. 1999). Protests at medical schools around the country, including a very active lobby amongst students and staff at UCT, led to the establishment in the 1980s of a set of anti-apartheid groups in health, which took up not only the protection of victims of political repression, but also began to explore issues of health policy needed for a post-apartheid South Africa (London 2004). University of Cape Town staff and students were active in networks providing medical and counseling support to political detainees and in programmes for the reintegration of returning exiles and released long-term political prisoners, and contributed to the establishment of the Trauma Centre for Survivors of Violence and Torture (TCSVT), a non-governmental organisation (NGO), offering mental health and social services for 
victims of repression and advocating against detention. They also participated in the early policy development work around primary health care through organisations such as the National Medical and Dental Association (NAMDA) (Coovadia 1999).

\section{Origins of the heALTH AND hUMAN RIGHTS PROGRAmme}

This involvement in anti-apartheid work by staff and students in the medical school at UCT laid the basis for future engagement around human rights issues on the campus in a way that has propelled research, teaching and social engagement for the University since the 1990s. The first formal UCT engagement in health and human rights began in partnership with the TCSVT in the early 1990s in the years before apartheid formally ended with the first democratic elections in 1994. Staff assisted the organisation in its work around the reintegration of returned exiles and political detainees through clinical service, research and advocacy. For example, staff alerted health professionals around the country about the likelihood of malaria amongst returned exiles by publishing a letter in a national medical journal based on research conducted for the Trauma Centre (London \& Zweigenthal 1993). However, the main collaboration with the TCSVT took the form of a 3-year funded initiative, the Health and Human Rights Project (HHRP), to develop a submission to the Truth and Reconciliation Commission (TRC) on health - subsequently published as a text on health, human rights and ethics, the first of its kind in South Africa (Baldwin-Ragaven et al. 1999) - and to assist the TRC organise its national health sector hearings (De Gruchy et al. 1998).

The collaboration with the TCSVT formed the basis for subsequent teaching, research and outreach, since it established the value base around which the university-NGO engagement was to take place - responsiveness to need, promotion of social justice, a focus on vulnerability, the use of research and professional skills to turn vulnerability into agency, and a recognition of the mutual benefits of such partnerships.

\section{Health AND hUman Rights teaching}

The initial focus of teaching was to run courses geared directly to undergraduate students in human rights (London et al. 1997). However, this initial teaching was offered as an optional module with 
the result that it self-selected students already concerned about social justice (London \& McCarthy 1998). Although there was space in the institution to initiate such teaching, there was no institutional interest or support at UCT at that time for fundamental curriculum change for medical students (Baldwin-Ragaven et al. 1998).

As a result, after the funded project with the TCSVT closed in 1998, the focus of the Health and Human Rights work shifted to teaching educators of students in a 'Train-the-Trainer' fashion. By running a short course for teachers geared toward introducing human rights into the curricula of health professionals at institutions across South Africa, it was hoped that the intervention would achieve a wider impact on the health sector, consistent with the vision of the TRC's recommendations for training aimed at changing the culture and practice of health professionals in South Africa. This reflected a shift away from an inward focus on the education of 'our' medical students to looking externally to engagement with and linking into social processes in health sciences education.

Since 1998, the Train-the-Trainer programme has trained over 200 staff from training institutions around South Africa, as well as NGOs, research agencies, Statutory Councils and Professional Associations (London \& Baldwin-Ragaven 2008). The programme provides participants with skills to begin to implement curriculum change in their own institutions, as well as skills related to teaching on human rights, and for promoting transformation. The learning objectives of a Train-the-Trainer course in health and human rights can be summarised as:

- advance conceptual understanding of human rights

- examine the relationship of professional/ethical codes to human rights

- explore institutional accountability

- recognise the importance of self-study and reflection

- explore strategies for curriculum change

- identify core and discipline-specific competencies

- share resources available

- build a network

It also integrates field visits to important human rights sites in Cape Town as part of experiential learning on the course. Trainees have included nurses, physiotherapists, doctors, community activists, 
NGO workers, and lawyers, all involved in some way in the training of health professionals. It has also included students as participants in the course; these students have engaged very effectively in discussions alongside teachers about curriculum design for human rights learning. Over the past three years, the course has included participants from African-wide human rights networks of health professionals. Support from the International Federation of Health and Human Rights Organisations (IFHHRO) has extended the profile and orientation of the training to a continental focus.

The importance of institutional engagement and self-reflection as being critical to mainstreaming human rights teaching, has been learnt first hand at the University of Cape Town, where a faculty-based transformation process has been ongoing since 1998, intended to ensure diversity and human rights are a component of a welcoming environment for staff and students (London \& Perez 2001). This has been a valuable experience that has informed the content of the Train-the-Trainer course in Health and Human Rights in recent years. Far from teaching just knowledge, or even skills, the course engages at a level that challenges participants to think about their own situatedness in relation to questions of privilege privilege formerly linked to racial groups in apartheid South Africa, but in current times more easily recognisable in multiple axes of disadvantage other than race.

Notably, UCT staff who have attended the Train-the-Trainer course have been instrumental in engendering curriculum change for UCT health sciences students (Duncan et al. 2006; Mayers 2007; London \& Baldwin-Ragaven 2008) and preliminary evaluations suggest that similar changes have been effected by staff at other institutions (Garcia et al. 2009). Curriculum redesign has enabled contentious human rights challenges (for example, termination of pregnancy) to find their way into the curriculum for health professional students in ways that enable students to reflect on their own values in relation to national human rights commitments. Students are, therefore, able to engage at a deeper level with formal teaching and apply these learnings in later years when they go out into communities to conduct health promotion projects in local settings with community stakeholders. Moreover, much of this development work around 
human rights in the curriculum has contributed to a national consensus that human rights are a core competency for graduates in the health professions (London et al. 2007). In 2007, the Health Professions Council of South Africa (HPCSA), the national regulatory body responsible for setting standards for medical student training, mandated training in human rights as a compulsory component of health professional training, alongside ethics and health law (HPCSA 2007). As a teaching activity responding to a particularly powerful need in South Africa, the course has also impacted fundamentally at the level of standard training for health professionals.

\section{HEALTH AND HUMAN RIGHTS RESEARCH}

Alongside teaching, and indeed integrated into teaching, has been a research focus of the HHRP reflecting its base in Public Health as an academic home. Health sector struggles during the antiapartheid period engaged in health policy but did not frame such policy engagement as socio-economic rights issues (London 2004). As a result, many of the post-apartheid challenges have continued to throw up contradictions for transformation, which are essentially human rights paradoxes similar to those identified by the Truth Commission. For example, in public criticism of the well-recognised resistance of the Minister of Health to the adoption of anti-retroviral medication, a letter to the newspaper pointed to the problem of 'dual loyalty' in health policy:

A minister of health is supposed to advise a president ... on the validity of medical research. What are Tshabalala-Msimang's medical qualifications? ... Did she swear the Hippocractic Oath and sign the Geneva Convention as all of us newly graduated doctors did? ... It seems that loyalty to the party overrides the deaths of thousands of our people and our raped babies. (Bain, JE, Letter to the editor, Cape Times, 14 March 2003)

One of the active areas of research run by the HHRP has therefore been to focus on the problem of 'dual loyalty' in the Health Professions, both in the delivery of clinical care (Rubenstein et al. 2002) and in the development and implementation of health policy (London 2002). Where health professionals allow third party interests to interfere in their professional obligations to patients and/or communities, they risk complicity in the violation of human rights. 
Work by the HHRP has taken the form of developing guidelines as part of an international working group (Rubenstein et al. 2002); providing/offering education and training initiatives for health professionals as part of Continuing Education courses; and advocacy at the level of professional regulation. Materials on 'dual loyalty' have also been used in undergraduate and postgraduate teaching. Extending the logic of rights-based approaches into public health policies (Gostin \& Mann 1994) has provided critiques of reproductive health policies for HIV+ women (London et al. 2008) and confinement policies for patients with drug resistant tuberculosis (London 2008a).

There has been a close link between teaching and research, consistent with UCT's vision of being a research-led university, manifested both in the use of research findings around 'dual loyalty' in teaching but also in the engagement of students, through their human rights-based research, with public debate about key health policies (for example, Mathews 2006) or in applying their analytical skills related to human rights to public health policies in their thesis research (Mall 2007). In much of this, the teaching and research has necessitated strong cross-disciplinary work, not always easy to achieve. For example, finding examiners that are able to locate themselves comfortably at the interface between social science, epidemiology and law has been a challenge for validating this type of scholarly work. Nonetheless, the importance of such work for contributing to changing public health policy (London 2006) has made such efforts worthwhile.

A second perspective to the research work undertaken has been a focus on issues affecting vulnerable groups (London et al. 1998; London 2003; London 2005; Naidoo et al. 2008). Putting vulnerable groups first is critical to a human rights approach and the research activities therefore reflect the human rights perspective both in content and approach. Two case studies illustrate this focus on vulnerability. The first involves farm workers in the Western Cape who suffer the legacy of the DOP system, an arrangement which allowed for the provision of alcohol as part of the remuneration of farm workers, introduced by early colonialists in the 17th century in South Africa to control indigenous labour. Although no longer legal, the consequences of this system persist in the form of widespread alcohol abuse and alcohol dependence. As a result, farm 
worker communities continue to experience high rates of poverty, social disruption and alcohol-related illness and injury (London 1999), including rates of Foetal Alcohol Syndrome (FAS) that are the highest in the world (May et al. 2006). Research responding to this need led to the establishment of the DOPSTOP Association as an NGO in collaboration with other universities, farmers, farm worker representatives, and the local health services to address the problem of alcohol abuse in rural farming communities. DOPSTOP has provided opportunities for students and staff to apply the principles of the Ottawa Charter on Health Promotion (World Health Organisation 1986) in their engagement with health services, policy interventions, advocacy and training and empowerment of communities most affected by alcohol.

Lessons learnt in the context of the DOPSTOP, particularly around how to ensure sustainability of such community-based interventions, have been applied to other connected research projects. For example, a large collaborative project funded by the Centre for Diseases Control in the USA to test different approaches to FAS prevention in a rural district north of Cape Town (Morojele et al. 2009) has been better able to anticipate how to hand over to community stakeholders a workable and sustainable intervention plan.

A second example of vulnerability relates to research aimed at extending the right of access to health care for Deaf people in Cape Town via professional interpreting services (see, for example, Heap \& Morgans 2006). Here, Deaf refers to those who are born deaf or who become deaf as children and whose first language is South African Sign (SASL). The project emerged from a long-term social anthropological study that investigated how Deaf people strategize to deal creatively with being deaf and marginalized in a dominantly hearing society (Heap 2003; Heap 2006). The project work has involved undergraduate health science students working alongside and learning from - Deaf research assistants. Outputs have been both academic and in the area of advocacy, with the students and Deaf people collaborating to produce a pamphlet of guidelines to assist health care staff (Heap et al. 2006) and a DVD submission by Deaf people in SASL to a Human Rights Commission Hearing on Access to Health Care (Heap 2007a). Subsequent phases of the project have started piloting a professional SASL language interpreter service for health care (see Haricharan \& Heap 2009). 
Through the project, Deaf people have begun to occupy and use space within the academe, working alongside other researchers in shared research offices and being visible through SASL and SASL interpreting at official university events, such as selected public lectures and seminars (Heap 2007b). Moreover, as researchers themselves, Deaf people have become agents for knowledge generation and advocacy that would not have been possible without the flexibility and accommodation that has emerged from a commitment to human rights by the institution. Without being planned as such, this project has been able to demonstrate the cogency of a conceptual framework developed in seemingly unrelated human rights research for the Network on Equity in Health in Southern Africa (EQUINET), which explored a set of case studies to derive a model for framing a rights approach. This model recognised the agency of the most vulnerable in society as critical to advancing equity in health (London 2007) and this was largely 'lived out' in the work with the Deaf.

The importance of recognising agency as being critical to realizing the right to health was tested further in a pilot study with three local civil society organisations (CSOs), which explored their understanding and use of rights in their work on health (Thomas \& London 2006). The study identified the need for information, support and networking in order to help them engage with the state and led on to the establishment of a Learning Network on Health and Human Rights (London 2008b). The Learning Network created a productive and respectful space for CSOs to explore how to best adopt human rights strategies in their work, using a mix of qualitative and quantitative research to identify best practice, develop training and advocacy materials, and disseminate experiences more broadly. Some of the outputs of this participatory research have been used in advocacy engagement as outlined below. Network members play active roles in determining the type of research and training needed through an independent Executive Committee structure.

\section{OUtREACH AND ADVOCACY IN HEALTH AND HUMAN RIGHTS}

The People's Health Movement (PHM) is an international civil society movement dedicated to the realization of health as a right, and aims to achieve this through concerted civil society action 
(Chowdhury \& Rowson 2000). In 2005, the PHM established a South African chapter that has relied heavily on involvement by HHRP staff and researchers, and on outputs generated through the research activities of the Health and Human Rights programme at UCT. Both undergraduate and postgraduate student involvement has been key to sustaining the research activities and to shaping student consciousness about community agency in health. Through involvement with PHM, UCT staff and students as well as visiting interns have contributed to strengthening its Right to Health campaign and advocacy inputs, such as submissions to national policy hearings, community-based campaigns and media.

In large part, this collaboration reflects the underlying values of human rights outreach as expressed in scholarly engagement to enhance social justice. Another example in which HHRP advocacy has been socially responsive has been in the field of HIV / AIDS in South Africa, where state policy has been particularly ambivalent, if not openly hostile to CSOs promoting the rights of poor people to care (Schneider \& Stein 2001; Heywood 2004). The Health and Human Rights Project inputs have strengthened public interest litigation challenging employment-based discrimination against persons with HIV (related to denial of employment to HIV+ persons in the national airline and the military forces), as well as assisting a court challenge against Ministerial support for and Departmental tolerance of the illegal distribution of and experimentation with unregistered medicine by a German entrepreneur in South Africa (AIDS Law Project 2008; Treatment Action Campaign 2008).

Consolidating such advocacy has required novel forms of communication and dissemination. The HHRP set up two electronic list servers, one generally on health and human rights (see Health \& Human Rights [hhrnet] at http: / / www.hst.org.za/ generic/31) and the other, a closed list specifically for trainees aimed at teaching in health and human rights. The list servers have enabled rapid dissemination of information, invitations to join petitions or other forms of direct action, and raised wider awareness of health and human rights crises. 


\section{INFUSING A HUMAN RIGHTS PERSPECTIVE INTO ACADEMIC WORK}

As universities grapple with the challenges of what forms of knowledge production are needed in the new millennium (Muller \& Subotzky 2001), it is clear that realizing a commitment to the public good must be broader than just enhancing economic productivity for national development (Gibbons 1998; Bawa 2003). Rather, such an endeavour should embrace wider conceptions of engaged and active citizenship (Talloires Network 2005). Confirming human rights as part of a health professional's responsibilities and identity (London \& Baldwin-Ragaven 2006) is thus consistent with not only national but also international trends in higher education, as well as professional ethics governing the health professions.

The current work in the HHRP has a strong sense of continuity with the earlier activist involvement of programme staff in antiapartheid activities, including health activism in the trade unions (London 1993) and in support for victims of political oppression (Baldwin-Ragaven et al. 1999). Academics moving from such arenas bring with them experience, insights and commitment to train health professionals to be sensitive to health and human rights issues and to inspire students to work in the public and NGO sectors. In addition, incorporating findings from research investigating discrimination within the university into teaching programmes (Perez \& London 2004; Ismail 2007; London et al. 2009a) has played an important role in informing the university's own strategies for transformation as well as locating research directly in a rights context within the institution.

Taking up human rights as an engaged academic activity has also forced staff to step outside disciplinary boundaries and to pursue transdisciplinary and transinstitutional work, characteristic of socially responsive research (Gibbons 1998). For example, much of the work has involved interactions with lawyers, adult educators, development practitioners, media experts and political scientists. Human rights are about promoting wellbeing, so human rights related research must touch everyday life as it affects everyone everywhere, involving contact with all kinds of people and organisations, without which it would not be possible to do the research.

This is particularly well illustrated in the opportunities presented to anthropologists working in this field. It is often suggested that it 
is hard for anthropologists to disentangle their roles as researchers from their roles as citizens. But human rights allow them to engage, critically and constructively, as citizens and academics, to combine social activism and ethnography (Heap 2007a). In the process, the anthropologist explores what making real the promise of the South African Constitution actually means at the level of the lived experience of ordinary people. At this level, anthropology can contribute a rich ethnographic texture and theoretical innovation about the lived experience of marginalisation and human rights discourse to the body of knowledge and practice in the health and human rights field.

A key challenge is to build a critical mass of researchers who can develop a coherent theoretical framework for human rights and health work and translate this into changes in the conditions of ordinary people, consistent with Nyden's argument (2005) that engaged research must lead to change with and by those affected by the subject under study. Research findings from various projects within the programme have shown, firstly, the limitations of an approach to rights which depends solely on litigants having to go to court to demand their rights and, secondly, that for rights to be realized, people have to become agents in changing the conditions which allow their rights to be violated (London 2004; London 2007). This recognition of community agency has formed the basis of the programme's involvement in the People's Health Movement and in developing a Learning Network on Health and Human Rights, which combines training and research in a dialectical relationship and which affords space for researchers to participate in the network whilst simultaneously and collaboratively researching the networking process.

However, as pointed out by Muller and Subotzky (2001), socially engaged research is not inevitably less likely to reproduce power relations than what Gibbons (1998) terms Mode 1 or traditional approaches to research. Rather, the recognition and tackling of power relations in research has to be actively pursued. For example, a paper that emerged from research with farm workers exposed to pesticides explored genetic susceptibility to pesticide risks. The paper (Lee et al. 2003) won an award for scientific quality from an international 
journal but attracted criticism from activists because of the possibility that categories of workers known to be genetically susceptible could be excluded from employment; this highlights the difficulties of doing research in the context of vulnerability, even when the intent is to highlight such vulnerability.

Learning from this experience means that researchers must be more sensitive to how research findings are presented and must involve communities directly in discussions about the research design and the collection, use and interpretation of data (Nyden 2005). For example, several of the Deaf field workers who assisted the department to do a baseline survey of the health and communication experiences of Deaf people in Cape Town have become 'shapers' of the research rather than interpreters of signed communication for other researchers (Heap et al. 2006).

Knowledge transfer has been a key component of how research and training can best improve communities' rights of access to health care. Over and above publishing articles in academic journals, research findings and information have been developed as pamphlets and posters on human rights for civil society. People who have completed the Train-the-Trainer course are added to a designated list server that disseminates information around human rights training issues, as well as case studies, materials and related training resources. The programme has made available, under open access copyright, the manual used in the Train-the-Trainer course, so that alumni of the course can use or adapt components of, the whole course, for further curriculum change (http: / / www.hhr.uct.ac.za/ train/ train. php). The EQUINET website (http:/ / www.equinetafrica.org) has been used to post research findings and information and serves as an important authoritative source for information on equity and health in the region, providing free access to activists, researchers, policy-makers and other stakeholders. Most recently, the EQUINET health rights theme, jointly coordinated by the Health and Human Rights programme at UCT with colleagues at the University of the Western Cape, has engaged with parliamentarians in southern Africa responsible for health through research, inputs and policy briefs (EQUINET 2008a; EQUINET 2008b; London et al. 2009b).

Extending such engagement with key policy-makers is part of academic responsibilities, whether in the form of submissions 
to government and other agencies, such as the Human Rights Commission, or in promoting public dialogue on human rights challenges in health affecting society. This has manifested in articles in the press and popular journals or newsletters to promote awareness of these issues.

\section{MEASURING THE IMPACT OF THE HEALTH AND HUMAN RIGHTS PROJECT}

The HHRP programme has sought to build in some form of evaluation into all their projects. For example the impact of their training course is the subject of a current follow up study by Garcia et al. (2009). However it is not always easy to identify appropriate indicators for assessing the impact of human rights work. For example, the programme's understanding that collective conceptions of rights are as important, if not more so than individualist claims, for realizing the right to health, means that typical indicators based on individual knowledge, attitudes and practices would fail to capture real impact.

Further, funding for such evaluations is often difficult to secure in the absence of quantitative statistics. Impacts are often at policy level and cannot be easily traced back to single interventions or research activities. For example, the decision of the HPCSA to mandate the inclusion of human rights, along with ethics and health law, as core competencies required of graduates in the health professions, was a consequence facilitated by the Train-the-Trainer programme, but which had many other antecedents and contributory components. Short of commissioning a labour intensive qualitative policy evaluation, the links between research activities and impacts will remain anecdotal. Nonetheless, this particular outcome represents a key milestone in ensuring that health professionals are better able to contribute to transformation in the new South Africa.

Further, academic reward systems for socially engaged research are not well developed (Nyden 2003). Conventional ways of measuring the impact of research, namely publication in peer review journals and citations, may not always be the most appropriate ways of measuring the impact of community-engaged research because of the importance of disseminate information in accessible ways, not only to realize the purpose of the research activity but also because that is a key aspect of this form of scholarship. For example, staff who publish 
high quality, peer-reviewed reports on public access websites may not gain adequate credit for such outputs in promotion processes, even if such websites are regarded as the most authoritative and popular sites for accessing information on the topic. This narrow approach does not take account that different kinds of research or scholarly outputs lend themselves to different forms of knowledge transfer or assessment of impact.

Most recently the Deaf Community of Cape Town (DCCT) has also started to take on responsibility for assessing their own health needs. In October 2007 they hosted a workshop to showcase their work on HIV / AIDS to health professionals, the Department of Health and other interested parties (Heap 2007c). The workshop formed part of their celebrations of 25 years as an NGO.

\section{Conclusion}

The University of Cape Town (UCT) has benefited from the community engagement; organisations in civil society view UCT as a source of support and they draw on UCT academics to support their work, resulting in a mutually beneficial relationship for them and the university. For example, organisations that tap professional skills to generate data to assist their advocacy have offered important sites for student learning. Similarly, many of the lessons learnt from the human rights research have assisted the Health Sciences Faculty's own transformation. The faculty has recently established a fellowship to support health and human rights research, addressing the impact of violence on health, partly as a response to societal challenges posed by criminal violence but also in direct response to instances where violent crime has led to the death or injury of university staff or family members.

Socially engaged teaching, research and advocacy in human rights has therefore been able to integrate both an inward and outward focus, allowing the institutionalization of the lessons derived from socially responsive scholarship. It has facilitated conceptual development in the field: moving from a narrow notion of human rights as civil and political freedoms, to recognising the increasing importance of engaging with socio-economic rights challenges in a developing country context; and going beyond a simple recognition of vulnerability to a focus on agency, which is instrumental to transforming human rights from 'rights on paper' to making rights real. 
Lastly, the human rights work has emphasized how important reflection is, both as an academic tool and activity and as an institutional imperative. Linked to this is the importance of role modeling for students. While official policies want to see university graduates committed to contributing to societal good, deeper engagement with stakeholders in the field of human rights and health offers huge opportunities to advance staff and students' understandings, as well as to help generate the critical citizenship needed to address challenges in health and human rights.

\section{REFERENCES}

AIDS Law Project 2008, 'Statement by the AIDS Law Project: Victory against the SANDF in HIV discrimination case', viewed 22 October 2009, http:/ / www.tac.org.za/ community / node/2295

Bain, JE 2003, 'Where's the evidence?', Letter to the editor, Cape Times, 14 March 2003.

Baldwin-Ragaven, L, De Gruchy, J, Lewin, S \& Walaza, N 1998, 'Health science faculties How committed are they to building a culture of human rights in health?', South African Medical Journal, vol. 88, no. 8, pp. 923-924.

Baldwin-Ragaven, L, De Gruchy, J \& London, L 1999, An ambulance of the wrong colour: Health professionals, human rights, and ethics in South Africa, University of Cape Town Press, Cape Town.

Baldwin-Ragavan, L, London, L \& De Gruchy, J 2000, 'Learning from our apartheid past: Human rights challenges for health professionals in contemporary South Africa', Ethnicity and Health, vol. 5, no. 3, pp. 227-241.

Bawa, A 2003, 'Rethinking community-based learning in the context of globalisation', Service Enquiry - Service in the 21st Century, vol. 1, no. 1, pp. 47-60, viewed 22 October 2009, http:/ / www.service-enquiry.org.za/first edition download.asp.

Coovadia, HM 1999, 'Sanctions and the struggle for health in South Africa', American Journal of Public Health, vol. 89, no. 10, pp. 1505-1508.

Chowdhury, Z \& Rowson, M 2000, 'The people's health assembly. Revitalising the promise of "Health for All"', British Medical Journal, vol. 321, no. 7273, pp. 1361-1362.

De Gruchy, J, London, L, Baldwin-Ragavan, L, Lewin, S \& the Health and Human Rights Project Support Group 1998, 'The difficult road to truth and reconciliation - The health sector takes its first step', South African Medical Journal, vol. 88, no. 8, pp. 975-979.

Department of Health [South Africa] 1997, Department of Health submission to the Truth and Reconciliation Commission, South Africa, viewed 22 May 2009, http:/ / web.uct.ac.za/depts/ hhr/ documents/Resources.pdf.

Duncan, M, Alperstein, M, Mayers, P, Olckers, L \& Gibbs T 2006, 'Not just another multiprofessional course! Part 1. Rationale for a transformative curriculum', Medical Teacher, vol. 28, no. 1, pp. 59-63.

EQUINET, TARSC and UCT in cooperation with SEAPACOH 2008a, 'Parliament roles in protecting rights to health in East and Southern Africa', Parliament Briefing 3, July 2008, EQUINET, Harare.

EQUINET, TARSC and UCT in cooperation with SEAPACOH 2008b, 'Using health rights to promote equity oriented health budgets', Parliament Briefing 4, July 2008, EQUINET, Harare. 
Garcia, DE, Baldwin-Ragaven, L \& London, L 2009, 'Training trainers in health and human rights: Implementing curriculum change in South African health sciences institutions', Manuscript in progress.

Gibbons, M 1998, 'Higher education relevance in the 21st Century', paper presented at UNESCO Conference on Higher Education, Paris, October 5-9.

Gostin, L \& Mann, JM 1994, 'Towards the development of a human rights impact assessment for the formulation and evaluation of public health policies', Health and Human Rights, vol. 1, no. 1, pp. 58-80.

Haricharan, HJ \& Heap, M 2009, '"Feeling Freedom": An anthropological perspective from Cape Town on professional sign language interpreter services equalizing access to non-discriminatory health care for Deaf South Africans', paper presented at the Fifth International Congress of Qualitative Inquiry, Advancing Human Rights Through Qualitative Research, University of Illinois, Urbana-Champaign, 20-23 May.

Health Professions Council of South Africa 2007, Proposed core curriculum on human rights, ethics and medical law for health care practitioners, Health Professions Council of South Africa, Pretoria.

Heap, M 2003, 'Crossing social boundaries and dispersing social identity: Tracing Deaf networks from Cape Town', PhD. thesis, Stellenbosch University, Stellenbosch, South Africa.

Heap, M 2006, 'Sign-deaf spaces. The Deaf in Cape Town creating community, crossing boundaries and constructing identity', Anthropology Southern Africa, vol. 29, nos. 1 \& 2, pp. $35-44$.

Heap, M 2007a, 'Language as a barrier to the right to have access to health care services. Professional interpreter services lifting barriers and equalizing access: The case of Deaf people who use South African Sign Language (SASL)', submission to the South African Human Rights Commission Public Enquiry into the right to have access to health care services in terms of Notice 162, 2007 Government Gazette, 16 February 2007, South African Human Rights Commission, Johannesburg, 2007.

Heap, M 2007b, 'Socio-economic rights and anthropology? The case of Deaf people who use South African Sign Language (SASL) in a university setting', Anthropology Southern Africa, vol. 30 , nos. 3 \& 4, pp. 135-142.

Heap, M 2007c, 'Communication experiences in health care in Cape Town of a sample of Deaf people,' paper presented at the Deaf Community of Cape Town (DCCT) seminar 'To create HIV / AIDS Awareness of the Needs of the Deaf', Southern Sun Hotel, Newlands, Cape Town, 1 October.

Heap, M, Bloch, J, Chan, C, Jacobs, B \& Mhlanga, S 2006, 'Feeling freedom. Professional interpreters in health care: Insights from Deaf people who use South African Sign language (SASL) - and guidelines for health professionals', paper presented at the Third Public Health Conference, Eskom Convention Centre, Johannesburg, South Africa, 15-17 May, viewed 22 October 2009, http:/ / www.phasa.org.za/images/conferences/phasa2006 abstract.pdf.

Heap, M \& Morgans, H 2006, 'Language policy and SASL interpreters in the public service', in M Watermeyer, L Swartz, T Lorenzo, M Schneider \& M Priestley (eds), Disability and social change: A South African agenda, HSRC Press, Pretoria, pp. 134-147.

Heywood, M 2004, 'The price of denial', Development Update, vol. 5, no. 3, pp. 93-122.

Ismail, S 2007, '"Did I say that?" A follow-up study of the shifts in black and women staff experiences of institutional culture in the Health Sciences Faculty of the University of Cape Town', Social Dynamics, vol. 33, no. 1, pp. 78-106.

Lee, BW, London, L, Paulauskis, J, Myers, JE \& Christiania, DC 2003, 'Association between 
human paraoxonase gene polymorphism and chronic symptoms in pesticide exposed workers', Journal of Occupational and Environmental Medicine, vol. 45, no. 2, pp. 118-122.

London, L 1993, 'The Ray Alexander Workers Clinic - A model for worker-based health services for South Africa?', Social Science and Medicine, vol. 37, no. 12, pp. 1521-1527.

London, L 1999, "The "dop" system, alcohol abuse and social control amongst farm workers in South Africa: A public health challenge', Social Science and Medicine, vol. 48, no. 10, pp.

1407-1414.

London, L 2002, 'Dual loyalties, health professionals and HIV policy in South Africa (Editorial Opinion)', South African Medical Journal, vol. 92, no. 11, pp. 882-883.

London, L 2003, 'Human rights, environmental justice, and the health of farm workers in South Africa', International Journal of Occupational and Environmental Health, vol. 9, no. 1, pp. 59-68.

London, L 2004, 'Health and human rights: What can ten years of democracy in South Africa tell us?', Health and Human Rights, vol. 8, no. 1, pp. 1-25.

London, L 2005, 'Childhood pesticide poisoning - A clarion call for action on children's vulnerability', South African Medical Journal, vol. 95, no. 9, pp. 673-674.

London, L 2006, 'A case for integrating human rights in public health policy', South African Medical Journal, vol. 96, no. 4, pp. 302-303.

London, L 2007, '"Issues of equity are also issues of rights": Lessons from experiences in Southern Africa', BMC Public Health, vol. 7, no. 14, viewed 22 October 2009, http:/ / www. biomedcentral.com/content/pdf/1471-2458-7-14.pdf.

London, L 2008a, 'Confinement in the management of drug-resistant TB: The unsavoury prospect of balancing individual human rights and the public good', South African Journal of Bioethics and Law, vol. 1, no. 1, pp. 1-9.

London, L 2008b, 'What is a human-rights based approach to health and does it matter?', Health and Human Rights, vol. 10, no. 1, pp. 65-80, viewed 22 October 2009, http:/ / www. hhrjournal.org/index.php/hhr/article/view/25/108.

London, L \& Baldwin-Ragaven, L 2006, 'Human rights obligations in health care', Continuing Medical Education, vol. 24, no. 1, pp. 20-24.

London, L \& Baldwin-Ragaven, L 2008, 'Human rights and health: Challenges for training nurses in South Africa', Curationis, vol. 31, no. 1, pp. 5-18.

London, L, Baldwin-Ragaven, L, Kalebi, A, Maart, S, Petersen, L \& Kasolo, J 2007, 'Developing human rights competencies for South African health professional graduates', South African Medical Journal, vol. 97, no. 12, pp. 1269-1270.

London, L, Kalula, S \& Xaba, B 2009a, 'A survey of trainee specialists experiences at the University of Cape Town (UCT): Impacts of race and gender', BMC Medical Education, vol. 9, p. 26, viewed 22 October 2009, http:/ / www.biomedcentral.com/1472-6920/9/26.

London, L \& McCarthy, G 1998, 'Teaching medical students on the ethical dimensions of human rights: Meeting the challenge in South Africa', Journal of Medical Ethics, vol. 24, no. 4, pp. 257-262.

London, L, McCarthy, G, van Heerden, J, Wadee, S, Walaza, N \& Winslow, T 1997, 'Preparing future doctors to meet ethical challenges: A training course for medical students in health and human rights', South African Medical Journal, vol. 87, no. 2, pp. 242-245.

London, L, Mbombo, N, Thomas, J, Loewenson, R, Mulumba, M \& Mukono, A (UCT, TARSC, SEAPACOH) 2009b, 'Parliamentary committee experiences on promoting the right to health in east and southern Africa,' EQUINET Discussion Paper 74, UCT, TARSC, SEAPACOH, EQUINET, Harare, viewed 22 October 2009, htt p:// www.equinetafrica.org/ bibl/docs/DISS74parlrights09.pdf. 
London, L, Nell, V, Thompson, ML \& Myers, JE 1998, 'Health status among farm workers in the Western Cape - Collateral evidence from a study of occupational hazards', South African Medical Journal, vol. 88, no. 9, pp. 1096-1101.

London, L, Orner, PJ \& Myer, L 2008, 'Even if you're positive, you still have rights because you are a person: Human rights and the reproductive choice of HIV positive persons', Developing World Bioethics, vol. 8, no. 1, pp. 11-22.

London, L \& Perez, G 2001, 'Reconciliation in the UCT Health Sciences Faculty: A vision for transformation', South African Medical Journal, vol. 91, no. 12, pp. 1027-1028.

London, L \& Zweigenthal, V 1993, 'Malaria among exiles returning to South Africa', South African Medical Journal, vol. 83, no. 9, pp. 694-695.

Mall, S 2007, 'The Impact of African traditional healers on ARV treatment in South Africa', Masters in Public Health Thesis, University of Cape Town, Cape Town.

Mathews, S 2006, 'Criminalising deliberate HIV transmission - Is this good public health?', South African Medical Journal, vol. 96, no. 4, pp. 312-314.

May, PA, Gossage, JP, Marais, AS, Adnams, CM, Hoyme, HE, Jones, KL, Robinson, LK, Khaole, NC, Snell, C, Kalberg, WO, Hendricks, L, Brooke, L, Stellavato, C \& Viljoen, DL 2006. 'The epidemiology of fetal alcohol syndrome and partial FAS in a South African community', Drug and Alcohol Dependence, vol. 11, nos. 2 \& 3, pp. 259-271.

Mayers, P 2007, 'Introducing human rights and health into a nursing curriculum', Curationis, vol. 30, no. 4, pp. 53-60.

Morojele, NK, London, L, Olorunju, SA, Matjila, J, Davids, AS \& Rendall-Mkosi, KM 2009, 'Predictors of risk of alcohol-exposed pregnancies among women in an urban and a rural area of South Africa', Social Science and Medicine (in press).

Muller, J \& Subotzky, G 2001, 'What knowledge is needed in the new millennium?', Organization, vol. 8, no. 2, pp. 163-182.

Naidoo, S, London, L, Burdorf, A, Naidoo, RN \& Kromhout, H 2008, 'Agricultural activities, crop production and pesticide use among women working in small scale farming in two areas of Northern KwaZulu-Natal, South Africa', International Journal of Occupational and Environmental Health, vol. 14, no. 3, pp. 218-224.

Nyden, P 2003, 'Academic incentives for faculty participation in community-based participatory research', Journal of General Internal Medicine, vol. 18, no. 7, pp. 576-585.

Nyden, P 2005, 'The challenges and opportunities of engaged research', in L Silka (ed.), Scholarship in action: Applied research and community change, US Department of Housing and Urban Development, Washington, DC.

Perez, G \& London, L 2004, “"Forty-five year apart”: Confronting the legacy of racial discrimination at the University of Cape Town', South African Medical Journal, vol. 94, no. 9, pp. 764-770.

Rayner, M 1987, Turning a blind eye? Medical accountability and the prevention of torture in South Africa, American Association for the Advancement of Science, Washington, DC.

Rubenstein, LS, London,L, Baldwin-Ragaven, L \& the Dual Loyalty Working Group 2002, 'Dual loyalty and human rights in health professional practice; Proposed guidelines and institutional mechanisms', International Dual Loyalty Working Group, Physicians for Human Rights and Health Sciences Faculty, University of Cape Town, viewed 22 October 2009, http:/ / physiciansforhumanrights.org/library/report-dualloyalty-2006.html.

Schneider, H \& Stein, J 2001, 'Implementing AIDS policy in post-apartheid South Africa', Social Science and Medicine, vol. 52, no. 5, pp. 723-731.

Talloires Network 2005, The Talloires Declaration on the Civic Roles and Social Responsibilities of Higher Education, The Talloires Conference, Talloires, France, 17 September 
2005, viewed 22 May 2009, http:/ / www.tufts.edu/talloiresnetwork/ downloads / TalloiresDeclaration2005.pdf.

Thomas, J \& London, L 2006, 'Towards establishing a learning network to advance health equity through human rights strategies', report to the Centre for Civil Society, University of Kwazulu-Natal, Durban, December 2006.

Treatment Action Campaign 2008, 'Cape High Court interdicts Matthias Rath and orders Government to investigate him and stop breaches of the Medicines Act. Victory for the rule of law and the scientific governance of medicines', viewed 22 October 2009, http:// www.tac.org.za/community/node/2348.

Truth and Reconciliation Commission 1998, Truth and Reconciliation Commission of South Africa Report, Volumes Two, Four, Five, Truth and Reconciliation Commission, Cape Town.

Van Heerden, J 1996, 'The meaning of the MASA apology', South African Medical Journal, vol. 86, no. 6, pp. 656-60.

World Health Organisation 1986, 'Ottawa Charter for Health Promotion', First International Conference on Health Promotion, Ottawa, 21 November 1986. WHO/HPR/ HEP/95.1, viewed 22 May 2009, http:// www.who.int/hpr/NPH/docs/ottawa charter hp.pdf. 